\title{
SITUASI KESEHATAN LINGKUNGAN DI KOTA CILEGON
}

Oleh:

WIDA SILVIA

\section{Program Studi Kesehatan Masyarakat Universitas Faletehan}

\section{Pendahuluan}

Kesehatan Lingkungan adalah upaya pencegahan penyakit dan/atau gangguan kesehatan dari faktor risiko lingkungan untuk mewujudkan kualitas lingkungan yang sehat baik dari aspek fisik, kimia, biologi, maupun sosial. (PP No.66 tahun 2014)

Upaya kesehatan lingkungan ditujukan untuk mewujudkan kualitas lingkungan yang sehat, baik fisik, kimia, biologi, maupun sosial yang memungkinkan setiap orang mencapai derajat kesehatan yang setinggi-tingginya. Upaya tersebut diselenggarakan melalui upaya Penyehatan, Pengamanan, dan Pengendalian secara terus menerus dan berkelanjutan untuk memenuhi Standar Baku Mutu Kesehatan Lingkungan dan Persyaratan Kesehatan. (PP No.66 tahun 2014)

Masalah kesehatan lingkungan dalam kehidupan masyarakat khususnya di Kota Cilegon, cukup mendesak dan merupakan prioritas dalam penangananya, disebabkan adanya interaksi manusia yang berhubungan langsung dengan lingkungan, memungkinkan untuk terjadinya penularan penyakit, keracunan, kecelakaan, pencemaran lingkungan dan gangguan kesehatan. Dengan demikian kesehatan lingkungan harus memenuhi persyaratan kesehatan dalam arti melindungi, memelihara, dan meningkatkan derajat kesehatan masyarakat.

\section{Hasil Kajian}

Pesatnya pembangunan dan pertumbuhan ekonomi di Kota Cilegon berperan penting dalam meningkatkan kesejahteraan masyarakat terutama status gizi masyarakat berbasis perilaku. Perilaku pemanfaatan pelayanan gizi dipengaruhi oleh dukungan suami, kebutuhan dan penghasilan keluarga.(Hayat, Arifiati, et al., 2021) Penggunaan bahan pengawet makanan formalin di pasar tradisional diperlukan upaya pengawasan dan penegakan hukum.(Hayat \& Darusmini, 2021) 
Perubahan lingkungan di Kota Cilegon berakibat pada derajat kesehatan masyarakat. Perkembangan kawasan industri di Kota Cilegon berakibat tingginya kadar klor bebas di Sungai Cidanau, (Hayat, 2020) perubahan kondisi kualitas air sungai Cibanten yang tercemar.(Hayat \& Kurniatillah, 2021)

Pesatnya pembangunan pelayanan kesehatan di Kota Cilegon, berdampak pada limbah medis yang dihasilkan.(Hayat, 2015) Diperlukan upaya pengendalian limbah medis di pelayanan kesehatan melalui praktik pengelolaan limbah medis yang memenuhi persyaratan kesehatan.(Hayat, 2012)

Pembangunan kawasan industri Kota Cilegon berdampak pada penyakit berbasis vektor seperti demam berdarah dan malaria. Pendidikan, Informasi dan Komunikasi diperlukan bagi masyarakat dalam pengendalian vektor DBD.(Hayat, Nurdiawati, et al., 2021) Deteksi dini penyaki malaria dalam upaya eleminasi penyakit malaria.(Hayat \& Kurniatillah, 2009) Peran masyarakat masyarakat dalam perilaku hidup bersih dan sehat melalui program cuci tangan pakai sabun efektif dalam pencegahan penyakit.(Hayat, 2021)

\section{Kesimpulan}

Potensi risiko kesehatan lingkungan di Kota Cilegon yang dapat mengancam kesehatan pekerja, lingkungan dan masyarakat, diperlukan upaya pencegahan dan pengendalian lingkungan yang sehat.

\section{Referensi}

Hayat, F. (2012). Pengaruh predisposing factor, Enable factor, Reinforcing factor terhadap praktik keselamatan kerja pada tenaga kesehatan dalam pengelolaan limbah medis padat di Puskesmas Wilayah Kota Cilegon tahun 2011. In Unpad Repository. Unpad.

Hayat, F. (2015). Analisis faktor pengelolaan limbah medis padat di Rumah Sakit Umum Daerah Kota Cilegon. Faletehan Health Journal, 3, 146-151.

Hayat, F. (2020). Analisis Kadar Klor Bebas (Cl2) dan Dampaknya Terhadap Kesehatan Masyarakat di Sepanjang Sungai Cidanau Kota Cilegon. Jurnal Kesehatan Masyarakat Mulawarman (JKMM), 2(2), 64-69.

Hayat, F. (2021). THE EFFECT OF EDUCATION USING VIDEO ANIMATION ON 
ELEMENTARY SCHOOL IN HAND WASHING SKILL. Acitya: Journal of Teaching and Education, 3(1), 44-53.

Hayat, F., Arifiati, N., \& Permatasari, T. A. E. (2021). Peran Dukungan Suami dan Faktor Lainnya terhadap Pemanfaatan Pelayanan Gizi oleh Ibu Hamil dengan Risiko Kurang Energi Kronis (KEK). Jurnal Keperawatan Silampari, 5(1), 125133.

Hayat, F., \& Darusmini, D. (2021). ANALISIS FAKTOR PENGGUNAAN FORMALIN PADA PEDAGANG TAHU DI PASAR TRADISONAL KOTA SERANG. Jurnal Surya Muda, 3(2), 121-132.

Hayat, F., \& Kurniatillah, N. (2009). Situasi Malaria di Kabupaten Lebak. Kesmas: Jurnal Kesehatan Masyarakat Nasional (National Public Health Journal), 3(6), 259-263.

Hayat, F., \& Kurniatillah, N. (2021). Microbiological and Water Quality Status of Cibanten River. The First International Conference on Social Science, Humanity, and Public Health (ICOSHIP 2020), 198-200.

Hayat, F., Nurdiawati, E., \& Kurniatillah, N. (2021). EDUKASI GERAKAN PEMBERANTASAN NYAMUK (PSN) DEMAM BERDARAH PADA ANAK USIA SEKOLAH DASAR DI KECAMATAN JAWILAN KABUPATEN SERANG.

Peraturan Pemerintah Republik Indonesia Nomor 66 Tahun 2014 Tentang Kesehatan Lingkungan 